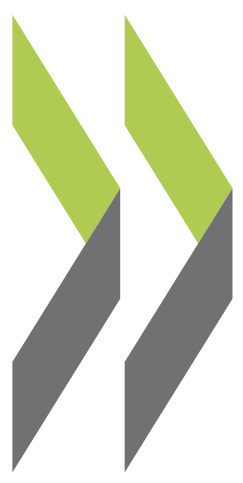

OECD Economics Department Working Papers No. 1086

The Agri-food Situation and Policies in Switzerland

\section{Peter Jarrett,}

Charlotte Moeser 


\section{Unclassified}

ECO/WKP(2013)78

Organisation de Coopération et de Développement Économiques

Organisation for Economic Co-operation and Development

12-Sep-2013

ECONOMICS DEPARTMENT

English - Or. English

THE AGRI-FOOD SITUATION AND POLICIES IN SWITZERLAND

ECONOMICS DEPARTMENT WORKING PAPER No. 1086

By Peter Jarrett and Charlotte Moeser

All OECD Economics Department Working Papers are available on the OECD's Internet website at http://www.oecd.org/eco/Workingpapers

JT03344299

Complete document available on OLIS in its original format

This document and any map included herein are without prejudice to the status of or sovereignty over any territory, to the delimitation of international frontiers and boundaries and to the name of any territory, city or area. 


\section{ABSTRACT/RÉSUMÉ}

\section{The agri-food situation and policies in Switzerland}

This paper examines the heavily supported Swiss food and agriculture sector. It reviews some of the key features and trends in the sector and reveals its low relative labour productivity in international comparison. It describes the existing policy regime, including its various forms of support and border protection, and the new law that will take effect in 2014 and goes on to make recommendations covering budgetary, environmental and trade aspects of Switzerland's policy regime.

JEL classification codes: Q10; Q15; Q16; Q17; Q18

Keywords: agriculture; food; farm; support; protection; subsidies; Switzerland

$* * * * * * * * * * * *$

\section{La situation et les politiques agro-alimentaires en Suisse}

Ce papier examine le secteur agricole et alimentaire suisse bien subventionné. It passe en revue plusieurs des traits marquants and des tendances sectoriels et révèle la faiblesse de la productivité relative du travail bas en comparaison internationale. Il décrit les politiques actuelles, y compris les multiples formes de soutien et de protection frontalière et la nouvelle loi qui entrera en vigueur en 2014 et procède à des recommandations couvrant ses aspects budgétaires, environnementaux et commerciaux.

Classification JEL : Q10 ; Q15 ; Q16 ; Q17 ; Q18

Mots clefs : agriculture ; alimentation ; agricole ; soutien ; protection ; subventions ; Suisse 


\section{Table of contents}

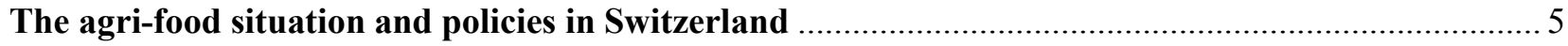

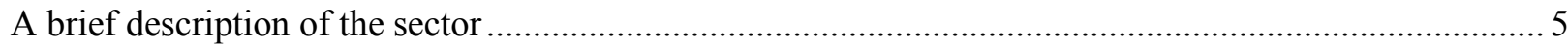

Agricultural support is generous by international standards .............................................................. 7

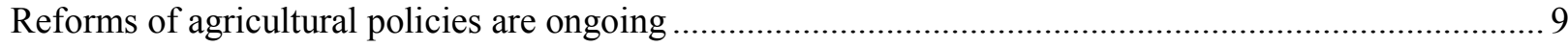

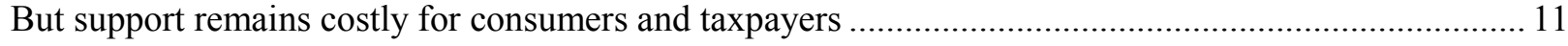

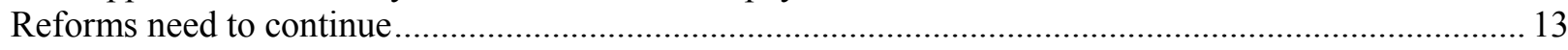

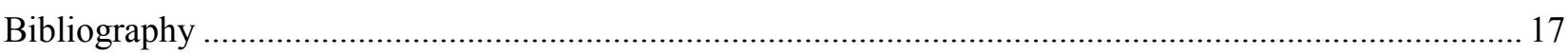

\section{Boxes}

1. The proposed new agricultural policy regime for 2014-17 ...................................................... 14

2. Recommendations for public policies covering Switzerland's food and agriculture sector ............. 16

\section{Tables}

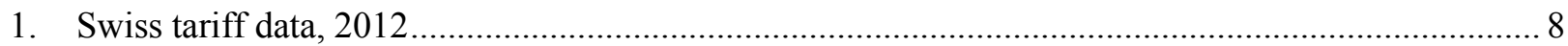

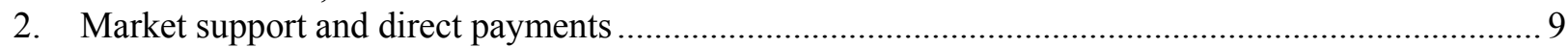

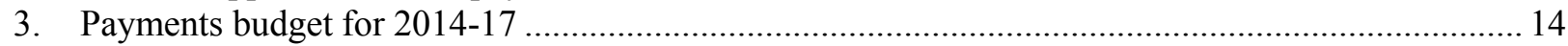

\section{Figures}

1. Switzerland's share of primary agriculture in GDP in OECD comparison, 2011 ........................... 6

2. Switzerland's share of primary agriculture in total employment in OECD comparison, 2010 ........... 6

3. Producer Support Estimate (PSE) as a percentage of gross farm receipts in OECD comparison........ 7

4. Switzerland's ratio of producer prices to border prices (NPC) ................................................ 10

5. Switzerland's most distorting support as a share of aggregate product support ............................... 10

6. Higher implicit transfers from consumers generally weigh on relative food prices ......................... 11

7. The relationship between policy measures to support producers on sectoral outcomes ................... 12

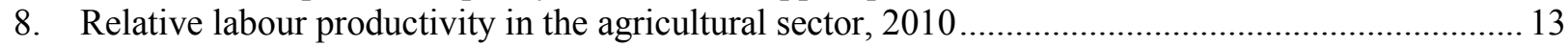

9. Share of public R\&D expenditure in total agricultural support in international comparison ............ 15

The statistical data for Israel are supplied by and under the responsibility of the relevant Israeli authorities. The use of such data by the OECD is without prejudice to the status of the Golan Heights, East Jerusalem and Israeli settlements in the West Bank under the terms of international law. 
ECO/WKP(2013)78 
ECO/WKP(2013)78

\title{
The agri-food situation and policies in Switzerland
}

\author{
Peter Jarrett and Charlotte Moeser ${ }^{1}$
}

\section{A brief description of the sector}

Switzerland's agricultural sector has recently called it "the Achilles heel" of the Swiss economy (WTO, 2013, p. 10). Its relative economic importance is low: in 2012 it produced around CHF 10 billion worth of product, but its gross value added was only about CHF 3.7 billion, less than $0.7 \%$ of GDP (Figure 1), down from $2.3 \%$ in 1990, as subsidies account for around two-thirds of factor income (compared to around $42 \%$ in the European Union). Agriculture's employment share was less than $4 \%$ (Figure 2), ${ }^{2}$ and it was responsible for $11 \%$ of Swiss greenhouse gas emissions. Agricultural employment has also been trending down over the past decade or so, from 204000 in 2000 to 164100 in 2011 (though $56 \%$ work part time, and officials (Lehmann and Lanz, 2012) argue that productivity is rising). Farming took up nearly a quarter of the country's surface area (excluding summer pastures) or about a million hectares in the mid-1990s when last measured. The sector is dominated by small family farms, which are mostly not globally competitive. ${ }^{3}$ Indeed, Switzerland is a net agro-food importer. ${ }^{4}$ Its level of self-sufficiency has remained relatively unchanged over the years at what seems a comparatively low share - around $63 \%$ in $2009 .{ }^{5}$ As elsewhere, Swiss agricultural policies aim at several objectives, such as ensuring security of food supply, conserving natural resources, diversifying land use and decentralising

1. Peter Jarrett is Head of Division in the Country Studies Branch of the Economics Department (email: peter.jarrett@oecd.org). Charlotte Moeser was Economist on the Switzerland/Indonesia Desk at the time of her contribution and is now Economist on the United Kingdom/Netherlands desk. The authors would like to thank Patrizio Sicari for statistical assistance, Mee-Lan Frank for editing and Frank van Tongeren, Richard Dutu and various Swiss experts from FOAG and SECO for useful comments and corrections. The views expressed herein do not necessarily represent those of the OECD nor its Member countries.

2. However, many more jobs are related to agriculture, most of it in upstream or downstream sectors (as many as one in ten).

3. There were 57617 Swiss farms in 2011, which are mostly small family enterprises; only about 40600 are operated by full-time farmers, and nearly a third of family income comes from non-farm sources. The number of farms has been falling steadily at least since 1990 when it was well over 90000 . At the same time the average age of farmers has been rising, with a fairly sharp drop in the number of farmers less than 40 since 2000 . More than half $(55 \%)$ of Swiss farms are located in hilly or mountainous regions; the receive $64 \%$ of all direct payments (FOAG, 2013, p. 12). The mean utilised size is 18.3 hectares, and only about 100 have more than 100 hectares. But there has been some consolidation: the mean size has edge up from 17.9 in 2000 . Nevertheless, by EU standards, this is fairly small: in the United Kingdom, Denmark, Germany and France it ranges from 54 to 84 hectares.

4. Switzerland's share of agro-food imports in total imports was around $6.2 \%$ in 2011 , while the share of agro--food exports in total exports was only some $3.75 \%$. The share of agricultural products in total imports has trended down over time, but Switzerland is said to be the top importer per capita of farm and food products. The share of agricultural products in total exports has increased slightly. Exports are dominated by items with heavy nonfarm value added, such as beverages, chocolate, dairy products and canned fruit and vegetables.

5. The self-sufficiency ratio was $95 \%$ for animal products but only $48 \%$ for plant products. 
settlement. Since 1996, these policy objectives have been anchored in the basic principle of multi-functionality within the Swiss constitution. ${ }^{6}$

Figure 1. Switzerland's share of primary agriculture in GDP in OECD comparison, $2011^{1}$

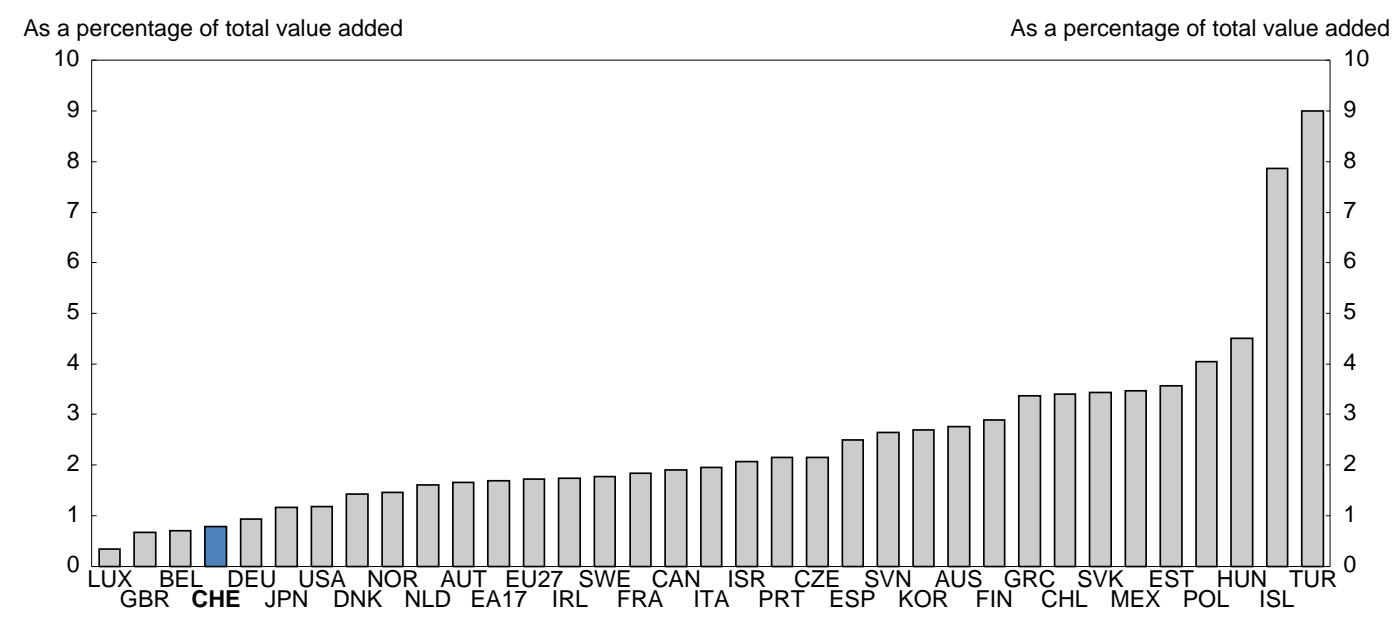

1. 2010 for Australia, Iceland, Japan, Mexico and the United States; 2009 for Israel and 2008 for Canada.

Source: OECD, National Accounts at a Glance 2013.

Figure 2. Switzerland's share of primary agriculture in total employment in OECD comparison, 2010

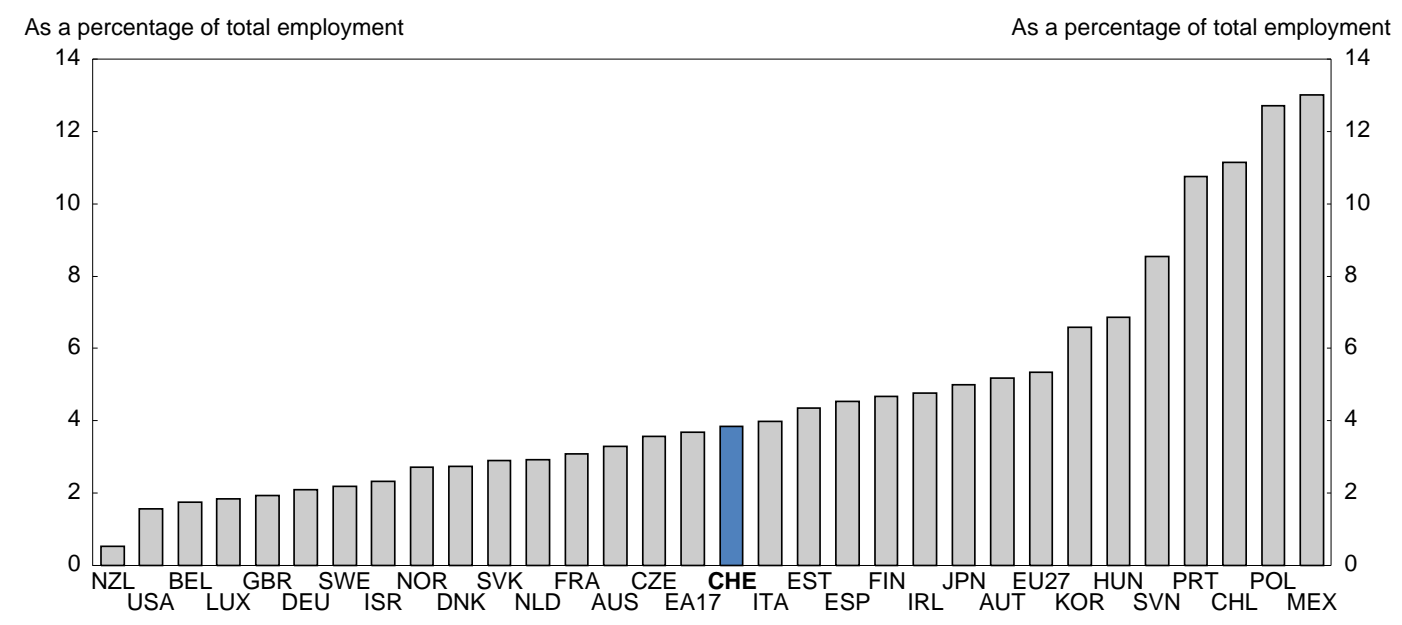

1. 2009 for Mexico and New Zealand; 2008 for Australia, France and Switzerland.

Source: OECD, National Accounts database.

6. Article 104 of the 18 April 1999 constitution was adopted by $78 \%$ of Swiss voters on 9 June 1996 . It specifically refers to the sector's multifunctional tasks. It requires the Confederation to ensure that agriculture contributes substantially with sustainable and market-oriented production to food security, resource conservation and upkeep of the rural landscape, decentralised settlement and utilisation of particularly environmentally friendly production methods. 


\section{Agricultural support is generous by international standards}

Even though it has come down since reform began in1993, support for agriculture remains high in OECD comparison. Producer support still accounts for more than half of gross farm receipts (Figure 3), $57 \%$ in 2012 to be precise. This compares with around 18\% producer support on average in the OECD and less than 4\% for producers in Australia, Chile and New Zealand (OECD, 2013). On the other hand, agricultural support has been progressively delinked from production and subjected to stricter conditionality than in many other OECD countries. While direct payments to farmers are conditioned on good environmental practices via the required "proof of ecological performance" ("cross-compliance") and the provision of public goods, instruments to support the agricultural sector also still include untargeted and distorting measures such as: market price support, border protection, export subsidies and refunds, and input subsidies.

Figure 3. Producer Support Estimate (PSE) as a percentage of gross farm receipts in OECD comparison

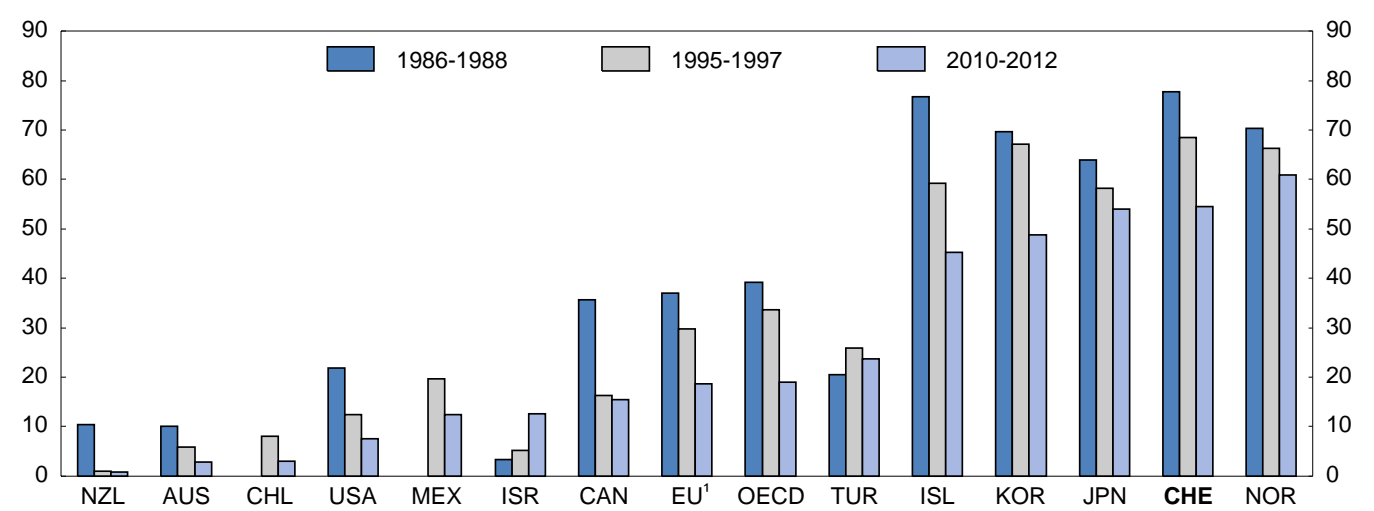

1. EU15 for 1986-88 and 1995-97; EU27 for 2010-12.

Source: OECD, PSE/CSE database 2013.

- $\quad$ Market price support. Guaranteed prices of many agricultural products were eliminated by 1999 . Yet, product-specific price support is still in place for many products, largely delivered by border protection and, to a smaller extent, market price support.

- Direct payments. There are two main categories: first, general direct payments (per hectare of farmland or per livestock unit), with less favoured areas getting preferential treatment. ${ }^{7}$ For example, farmers get an average of about CHF 50000 per farm in direct payments for working on steeply sloped terrain (this cost CHF 114 million in 2011) and contributing to public goods such as food supply security (CHF 1218 million). There are general direct payments per hectare and/or per livestock unit of about CHF 3 billion, as well as ecological direct payments and payments for animal welfare of about CHF 600 million. To apply for support, proof of ecological performance must be provided, showing that farms make balanced use of fertilisers and only limited use of pesticides, rotate crops frequently, and protect soil from erosion, and treat at least

7. These payments are degressive in size, animal numbers, income and assets (they are phased out over the range of 40-130 hectares and 55-190 livestock units with a ceiling on assets of CHF 1 million). The maximum amount is CHF 70000 per farm person (measured in standard labour units) per year. 
$7 \%$ of their farmland as ecological compensation areas (for example, extensive pasture set aside) ${ }^{8}$

- Border protection. The level of border protection is high: if converted to an ad valorem equivalent, tariffs averaged $31.9 \%$ in $2012,{ }^{9}$ some 14 times the corresponding level for non-agricultural items (Table 1). In some cases they are extremely high (especially for animal and dairy products). Agro-food imports are also regulated by a complex system of tariff rate quotas (TRQs), where tariffs are also higher than average. ${ }^{10}$ High or prohibitive out-of-quota MFN tariffs in import-competing sectors contrast with tariff-free imports in a range of products such as cotton with little or no domestic production. Tariff rates remain at a very high level by international comparison, more than double average world levels in 2011 according to the World Bank.

Table 1. Swiss import tariffs, 2012

\begin{tabular}{|c|c|c|c|c|c|}
\hline & $\begin{array}{c}\text { Number } \\
\text { of lines }\end{array}$ & $\begin{array}{c}\text { Average tariff } \\
(\%)\end{array}$ & $\begin{array}{c}\text { Range } \\
(\%)\end{array}$ & $\begin{array}{l}\text { Coefficient } \\
\text { of variation }\end{array}$ & $\begin{array}{l}\text { Share of duty- } \\
\text { free lines }(\%)\end{array}$ \\
\hline Total & 8299 & 9.2 & $0-1676$ & 5.3 & 18.7 \\
\hline WTO non-agricultural products & 6165 & 2.3 & $0-71$ & 1.7 & 18.8 \\
\hline WTO agricultural products & 2134 & 31.9 & $0-1676$ & 3.1 & 18.3 \\
\hline \multicolumn{6}{|l|}{ of which: } \\
\hline Animals and products thereof & 173 & 125.5 & $0-1676$ & 2.2 & 9.8 \\
\hline Dairy products & 58 & 101.5 & $1-1295$ & 1.8 & 0.0 \\
\hline Fruit, vegetables and plants & 617 & 28.1 & $0-549$ & 2.0 & 14.9 \\
\hline Coffee and tea & 62 & 8.4 & $0-76$ & 1.4 & 16.1 \\
\hline Cereals and preparations & 426 & 20.8 & $0-265$ & 1.3 & 10.3 \\
\hline Oils, seeds, fats, oil and their products & 394 & 22.5 & $0-137$ & 1.5 & 19.0 \\
\hline Sugars and confectionary & 58 & 6.9 & $0-60$ & 1.3 & 25.9 \\
\hline Beverages, spirits and tobacco & 124 & 25.1 & $0-509$ & 2.1 & 8.9 \\
\hline Cotton & 6 & 0.0 & 0 & 0.0 & 100.0 \\
\hline Other agricultural products, NES & 216 & 5.8 & 0.230 & 3.9 & 56.0 \\
\hline
\end{tabular}

Source: WTO (2013, Table 3.3).

8. Ecological compensation areas protect and restore ecosystems close to their natural state. No artificial fertilisers and pesticides are allowed. Overall, they represent $12 \%$ of utilised agriculture area.

9. All Swiss tariffs on agricultural products are specific, meaning their degree of protection varies with the exchange rate: the stronger the franc, the lower are import prices in franc terms and the higher is the ad valorem tariff equivalent. The figure for the 2012 average is therefore only indicative.

10. The system takes nearly 300 pages to describe; it comprises 28 tariff quotas (with 58 sub-quotas, 80 bilateral preferential tariff quotas) except for those under the Generalised System of Preferences where all imports are admitted freely. A few years ago items within the quota represented $18 \%$ of total agricultural imports but provided $29 \%$ of all customs revenues, while those outside the quota were only $2 \%$ of all such imports but paid $11 \%$ of all duties (DFE, no date, p. 4). Some TRQs are auctioned, some are allocated on a first-come first-served basis, some are based on past imports and some are contingent on local purchases (the so-called prise en charge system; see Jörin and Lengwiler (2004). The WTO (2013) opposed any shift back for the meat and meat product sub-quotas from auctioning (which began in 2007 and yields about CHF 150 million for government coffers, about half the estimated profit associated with the TRQs (Hofer, 2009, p. 19) to the former prise en charge system judged to be more discriminatory, but the parliament decided to do so in part nevertheless. 
- Export subsidies. While export subsidies on primary agricultural products were abolished at the end of 2009, a scheme is still in place to compensate exporting industries of processed agricultural goods for the high costs due to tariff protection of locally produced inputs (Schoggigesetz or loi chocolatière). This is done through tariff protection for locally processed agricultural products and export refunds for a certain share of the price premium between Swiss and foreign raw materials used in the production of processed agricultural goods for export. Indeed, downstream industries such as the food-processing sector producing internationally tradable goods benefit considerably from such export subsidies on processed agricultural products.

- Input subsidies. Producers have access to interest-free long-term investment credit provided by the federal government and administered by the cantons (with an average payback period of about 13 years), whose annual subsidy value is estimated to be worth CHF 47 million. As well, farmers benefit from area-based exemptions from some CHF 65 million per year in mineral oil tax.

\section{Reforms of agricultural policies are ongoing}

Since the early to mid-1980s, following the Uruguay Round Agreement and several bilateral trade accords, Switzerland has gone through a comprehensive agricultural policy reform (summarised in Hofer, 2009), accompanied by a shift towards enhanced market orientation, i.e. away from market price support ${ }^{11}$ towards direct payments (Table 2). Consequently, there has been a gradual reduction in the overall level of agricultural support. Producer support has fallen by around 20 percentage points of gross farm receipts since the turn of the century to some $56 \%$ today (Figure 3 above). ${ }^{12}$

Table 2. Market support and direct payments

CHF million

\begin{tabular}{|lrrrrrr}
\hline \multicolumn{1}{c}{ Measure } & 2007 & 2008 & 2009 & 2010 & $\begin{array}{r}2011 \\
\text { Average } \\
2014-17\end{array}$ \\
\hline & & & & & & \\
Market support expenditure ${ }^{1}$ & 493.2 & 481.4 & 434.0 & 372.2 & 385.4 & 381.0 \\
$\quad$ Dairy sector, of which: & 366.0 & 349.7 & 316.7 & 291.9 & 295.3 & 296.0 \\
$\quad$ Subsidy for milk processed into cheese & 255.1 & 261.0 & 247.8 & 256.3 & 259.5 & n.a. \\
$\quad$ Livestock sector & 18.2 & 18.3 & 18.3 & 10.2 & 12.4 & 13.0 \\
$\quad$ Arable sector, of which: & 109.0 & 113.4 & 99.0 & 70.1 & 77.7 & 69.8 \\
$\quad$ Crop premiums & 46.3 & 47.7 & 69.6 & 65.9 & 68.8 & n.a. \\
Direct payments & 2575.0 & 2505.0 & 2741.7 & 2789.2 & 2799.2 & 2814.0 \\
\hline
\end{tabular}

1. Including export subsidies.

Source: Federal Office for Agriculture, Rapport Agricole, various issues.

At the same time, support has been shifted from market price intervention towards direct payments (Table 2). Price support for major agricultural products has been reduced. Farmers were compensated through higher direct payments for losses in their income; direct payments have increased in importance

11. Market price support comprises all policy measures that raise the domestic price relative to the border price of the commodity concerned, including border measures (tariffs, tariff quotas and other import restrictions), administered prices and export subsidies.

12. The largest share of producer support in value terms was directed in 2012 at pork, followed by beef and milk. OECD PSE database 1986-2012, "Producer and Consumer Support Estimates: Switzerland". 
over recent years, accounting in 2011 for some $87 \%$ of all budgetary agricultural support, up from $83 \%$ in 2007. Despite these reform efforts, the prices paid to the farming sector were on average still 1.5 times world prices in 2009-11 (down from a peak of five times higher in 1988, in large part because world market prices improved) (Figure 4). This is mainly attributable to still high border protection. Although the amount of the most distorting forms of support has been significantly reduced, it still represents almost half the total (Figure 5).

Figure 4. Switzerland's ratio of producer prices to border prices (NPC)

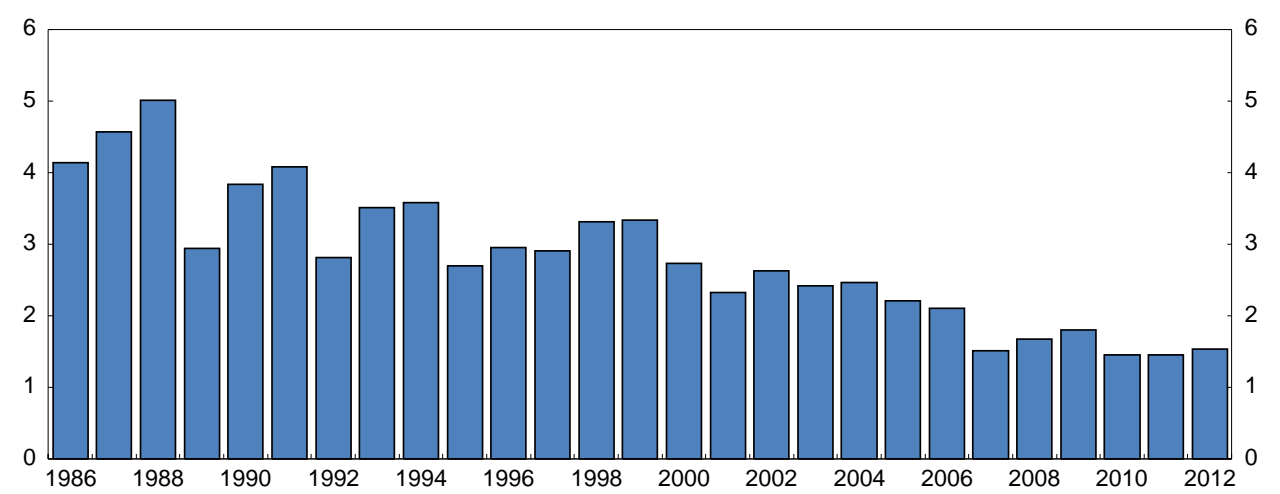

1. The Nominal Protection Coefficient (NPC) is an indicator of the protection for producers measuring the ratio of the average price at the farm gate, including payments per tonne of current output, to the border price.

Source: OECD, Agricultural Policy Indicators database.

Figure 5. Switzerland's most distorting support ${ }^{1}$ as a share of aggregate product support

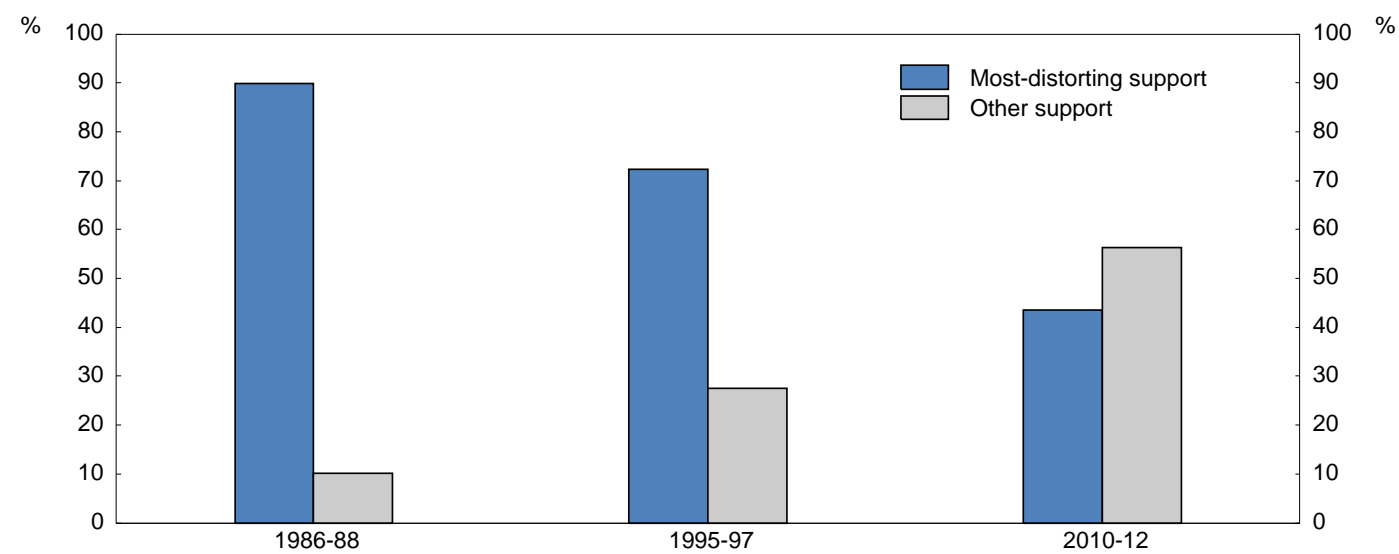

1. Most-distorting support is defined as that which is based on output and variable input use without input constraints. In effect, it is that which distorts the choice of outputs farmers make as well as the methods they use to produce them.

Source: OECD, Agricultural Policy Indicators database.

Further steps in the shift from market price support to direct payments are being implemented under Switzerland's current policy framework, Agricultural Policy 2011, which expires at the end of 2013. A few tariff reductions have been made - for example, there has been free trade in cheese with the EU since June 2007, and in recent years there has been a sizeable cut in bread cereal and wheat flour reference prices and a decline in feed grain import threshold prices - but tariffs remain high (see above). Also, greater 
flexibility and transparency were introduced in the administration of the TRQ system governing imports of dairy products. Milk price controls and the milk quota system were abolished on 1 May 2009, but surpluses persist; the compulsory milk levy that replaced it has drawn some international criticism (WTO, 2013, p. 11). The reduction in overall support over the past 20 years has lowered prices for all products (almost $30 \%$ for producers), but cuts to dairy prices were the most significant: consumer prices for dairy products were cut by $16 \%$ on average, while producer prices fell by $40 \%$ (FOAG, 2012a). In addition, as mentioned above, all export subsidies to primary agricultural products were eliminated in 2010. Yet, some export subsidies for processed products remain, on butter for example. The case of cheese is different, since all milk processed into cheese is subsidised, not only for exported cheese.

\section{But support remains costly for consumers and taxpayers}

The implicit tax on consumption of food (CSE) is among the highest in the OECD (along with Japan, Korea and Norway); it amounts to USD 46459 per farmer in Switzerland While support to the agricultural sector remains heavy, domestic consumer prices of most agricultural and food products continue to be very high. According to the Federal Economics Department (DFE, no date, p. 5) such prices are 28\% higher than those in neighbouring countries, of which 18 percentage points are due to higher downstream value added (processing and trade margins), 8 points to higher prices paid to farmers, and only 2 points reflect the direct impact of tariff and non-tariff trade barriers. By 2008, however, despite this absolute price gap, the relative price of food in terms of the domestic prices of other goods and services was not especially high: most prices are higher in Switzerland. This is somewhat of a surprise, since there is clear evidence that relative prices of food are generally higher the more negative is the CSE (i.e. the more taxed food consumption is) (Figure 6).

Figure 6. Higher implicit transfers from consumers generally weigh on relative food prices

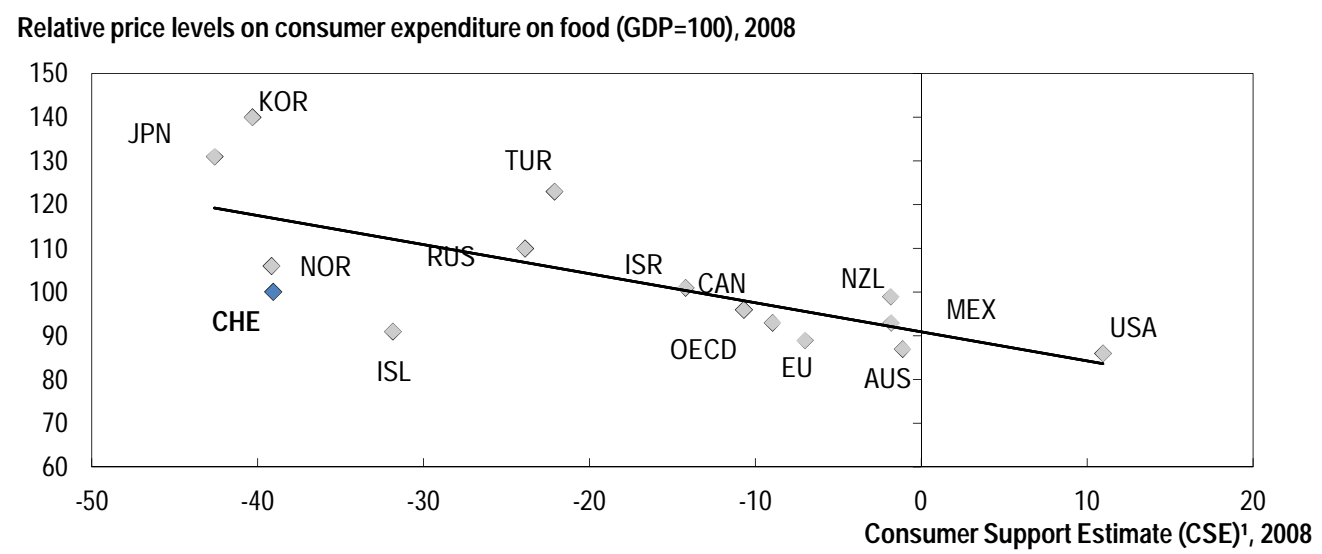

1. As a share of consumption expenditure on agricultural commodities, net of taxpayer transfers to consumers; CSE is the annual monetary value of gross transfers from/to consumers of agricultural commodities, measured at the farm level, arising from policy measures that support agriculture. When negative, transfers imply an implicit tax on consumption associated with agriculture support policies.

Source: OECD, Purchasing Power Parities and Agricultural Policy Indicators databases.

High levels of support also result in considerable costs for taxpayers. In 2011, total budgetary outlays amounted to CHF 3.6 billion, which is approximately $6 \%$ of total federal budgetary expenditures (or $0.6 \%$ of GDP) (BFS, 2011). Total support, as measured by the Total Support Estimate (TSE), amounted to just over $1 \%$ of GDP, $58 \%$ of which is paid for by taxpayers and $42 \%$ by consumers (OECD, 2013). In addition, countries with higher percentage Producer Support Estimates (PSEs) tend to have smaller shares of output and employment in agriculture (Figure 7, Panels A and B), but the former relation is stronger, 
Figure 7. The relationship between policy measures to support producers and sectoral outcomes

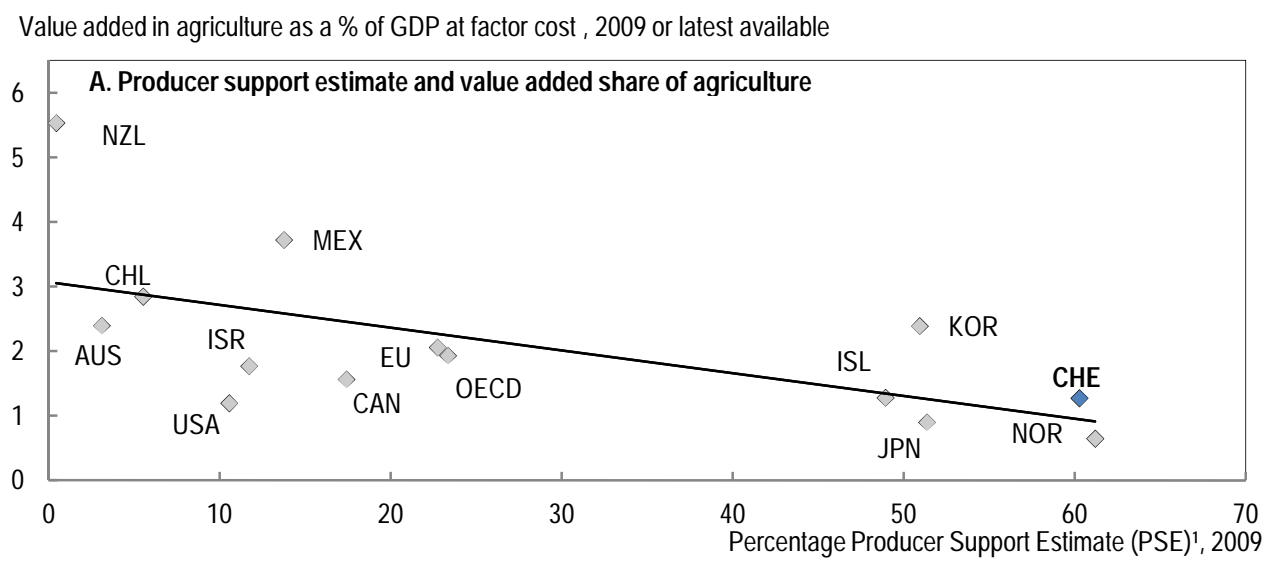

Employment in agriculture as a \% of total employment, 2009 or latest available

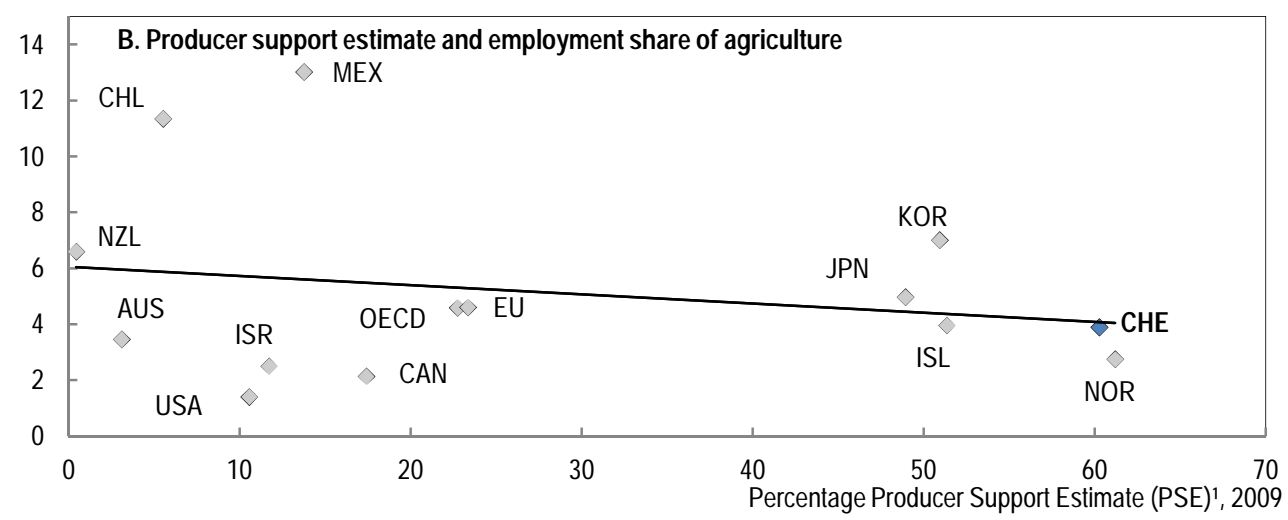

Ratio of agriculture's shares in total value added to employment, 2009 or latest available

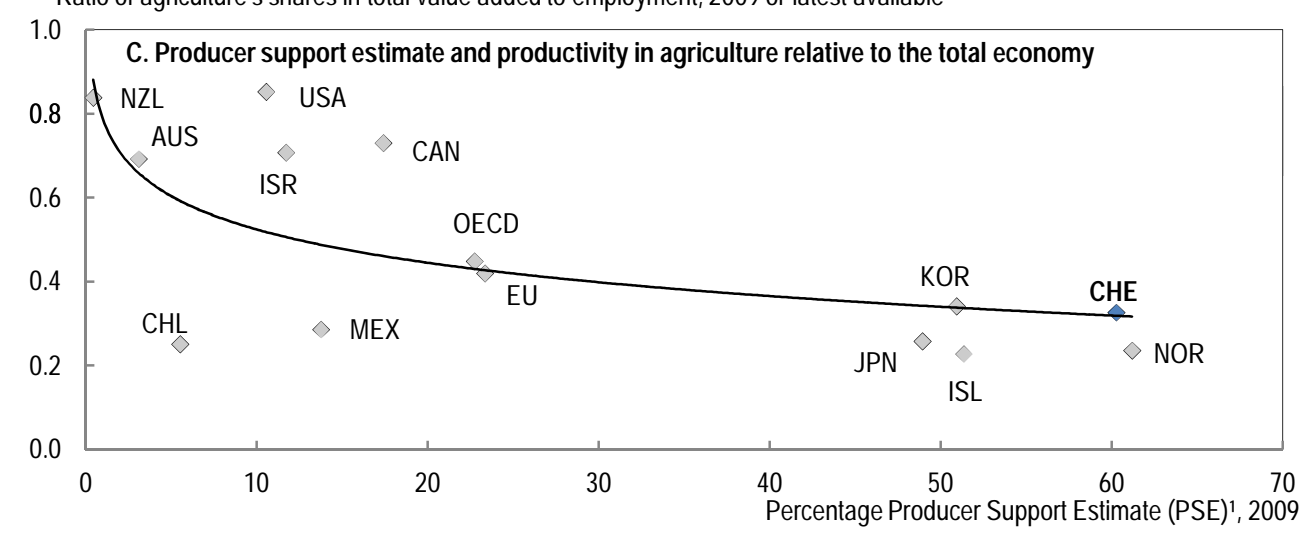

1. PSE is the annual monetary value of gross transfers from consumers and taxpayers to agricultural producers, measured at the farm-gate level, arising from policy measures that support agriculture. Percentage PSEs are PSEs as a share of gross farm receipts.

Source: OECD, STAN, National Accounts and Agricultural Policy Indicators databases.

arithmetically resulting in lower labour productivity as well (Panel C and Figure 8 ), ${ }^{13}$ even if the direction of causality cannot be ascertained. Nevertheless, it can be argued that Switzerland's heavy support sustains inefficient farming structures. Only about a fifth of Swiss farms in lowland areas are as efficient as the

13. Unfortunately, no sectoral multi-factor productivity data exist for Switzerland. 
average farm in neighbouring Baden-Württemberg (Germany), which has similar topographical conditions (FOAG, 2011). If all Swiss farms were as efficient as the currently top $25 \%$, the gain could be more than $1 \%$ of GDP (OECD, 2012) if the freed-up labour achieved economy-wide average productivity.

Figure 8. Relative labour productivity ${ }^{1}$ in the agricultural sector, 2010

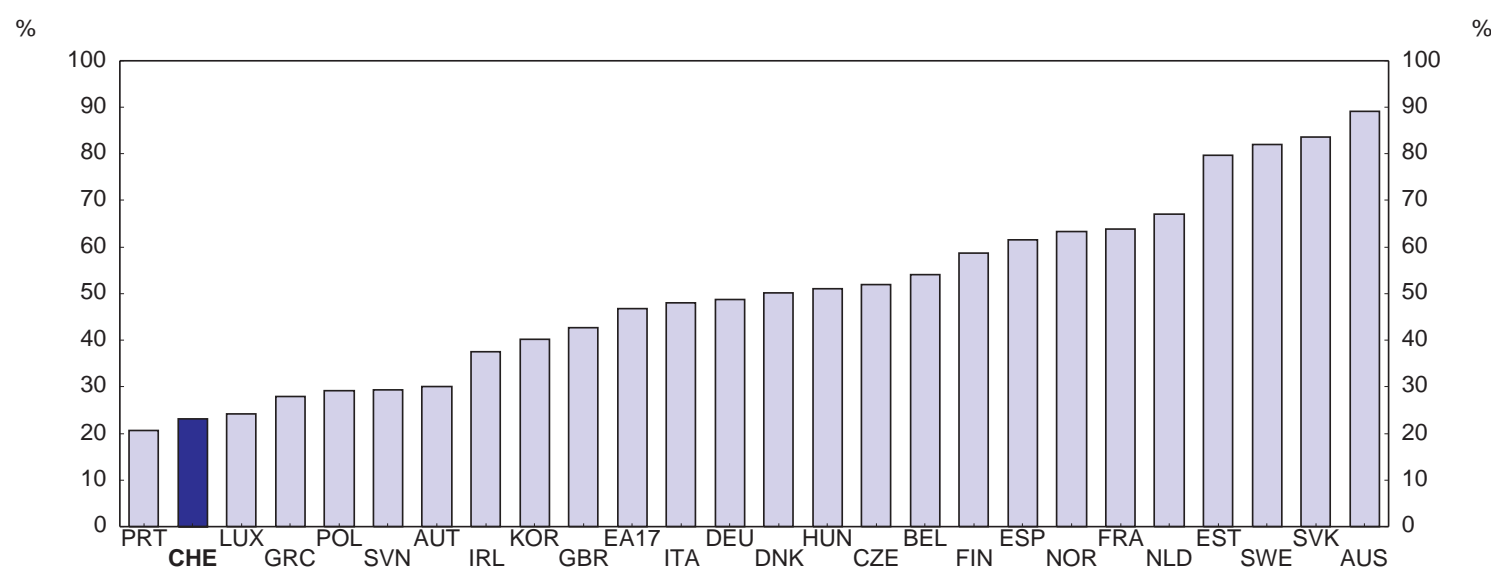

1. Nominal value added per employee in agriculture relative to the total economy.

Source: OECD.

\section{Reforms need to continue}

Although much progress has been made in the past 20 years to reduce the distortionary impact of agricultural support and lessen the negative environmental impact of agricultural production, the pace of reform has slowed down and barriers to structural change in agriculture remain important, especially as regards farm land. For example, even if they have been eased somewhat in the past, inheritance rules stipulate that an heir wishing to maintain a middle-size or large farming business is given preference over other heirs and that such an heir may compensate the others for their shares at values below market prices, thereby biasing land and capital-use decisions towards farming and locking in resources in the sector (OECD, 2007). This is especially damaging when the farm in question is otherwise non-viable. Price controls on agricultural land have similar effects. The authorities could go further in encouraging structural change by tying income support to individual incumbent farmers, rather than their businesses so expectations of future support do not bias heirs' decisions.

Switzerland has been in negotiations on further reductions of agricultural support and liberalisation of the sector under the framework of the Doha round and in accompanying bilateral talks with the European Union (EU). However, progress in the Doha round has come to a halt, and political support in Switzerland for a bilateral agreement with the EU has apparently vanished. Nevertheless, the Swiss parliament approved new legislation on 22 March 2013 covering the years 2014-17 that rearranges an unchanged amount of direct payments toward broader public-interest objectives and to try to remove conflicts with WTO "Green Box" criteria (those payments that are allowed without limit) (WTO, 2013, p. 11) (Box 1). 


\section{Box 1. The proposed new agricultural policy regime for 2014-17}

The general aims of the new policy regime are to improve the competitiveness of Swiss agriculture with an increased emphasis on product quality in order to access new markets, increase the services provided by farmers for the community (ensuring food supplies in particular) and the efficient use of resources in farm production and to minimise the negative effects of farming on the environment (Lanz, 2012). More precisely, its most important measureable objectives are: to raise net and gross production slightly; to slow the trend annual decline of farm incomes from $0.7 \%$ to below $0.5 \%$, the loss of farmland from 1900 hectares to less than 1000 hectares per year and reduce the natural spread of forests by $20 \%$; to boost nitrogen and phosphorus efficiency by 4 and 9 percentage points, respectively and biodiversity strips by 5000 hectares; and, finally, to cut methane emissions by more than $15 \%$.

Besides overhauling the direct payments system within a constant budget envelope of some CHF 2.8 billion per year $(82 \%$ of total measures) (Table 3 ), the legislation will shift some support from livestock and dairy producers to arable land production. Within the direct payment category there are to be more targeted payments for ensuring food supplies, maintaining and developing biodiversity and landscape quality, implementing certain production systems and achieving resource efficiency matched by a corresponding decline in transition payments. The new regime will likewise eliminate income/asset limits (except for transition payments) and no longer set size limits based on the number of animals but on acreage with minimum stocking density. And it will lower milling wheat customs duties slightly (by CHF 300 per tonne). Consideration was originally given to cut the CHF 0.15 per kg for milk processed into cheese, but the parliament refused that change.

Table 3. Payments budget for 2014-17

CHF million

\begin{tabular}{|lrrr}
\hline \multicolumn{1}{c}{ Measure } & 2014 & 2017 & Total 2014-17 \\
\hline Basic improvements and social measures & 199 & $\mathbf{2 0 0}$ & $\mathbf{7 9 8}$ \\
\hline Secondary social measures & 3 & 3 & 12 \\
\hline Subsidies for structural improvements & 99 & 99 & 396 \\
\hline Investment loans & 47 & 47 & 188 \\
\hline Arable and cattle farming & 38 & 38 & 153 \\
\hline Production and sales & 442 & 447 & 1776 \\
\hline Promotion of quality and sales & 60 & 70 & 262 \\
\hline Dairy farming & 296 & 296 & 1184 \\
\hline Cattle farming & 13 & 13 & 52 \\
\hline Arable farming & 73 & 69 & 279 \\
\hline Direct payments & 2814 & 2814 & 11256 \\
\hline Subsidies for ensuring food supplies & 1094 & 1094 & 4376 \\
\hline Farmland subsidies & 511 & 511 & 2044 \\
\hline Subsidies for biodiversity & 295 & 338 & 1264 \\
\hline Subsidies for quality of landscape & 20 & 90 & 210 \\
\hline Subsidies for production systems & 361 & 403 & 1526 \\
\hline Subsidies for efficient use of resources & 52 & 73 & 256 \\
\hline Transition subsidies & 482 & 306 & 1579 \\
\hline Total & 3455 & 3461 & 13830 \\
\hline
\end{tabular}

Source: Lanz (2012), updated by the Swiss authorities.

The government engaged some modelling work to look at the impact of the changes (Zimmermann et al., 2011 and 2012; FOAG, 2012b). It shows farm incomes will be $4.2 \%$ higher than under an unchanged policy scenario, which will allow the average farmer to maintain his/her real income level. While total livestock numbers will fall by around $10 \%$, total calories produced will rise by around $3 \%$ because of higher dairy yields and a shift toward arable farming and thus lower feed imports. Less intensive livestock production will lower excess residual production of nitrates and phosphates* as well as greenhouse gases and improve the sector's impact on biodiversity. There is an intermediate target for ammonia $\left(\mathrm{NH}_{3}\right)$ emissions of 44000 tonnes, down from 49000 tonnes in 2010; the ultimate target is 25000 tonnes (Chavaz, 2013).

* The nitrogen surplus has fallen by $25 \%$ since 1985 to some 102000 tonnes, the phosphorus surplus by $65 \%$ since 1990/92 and pesticide use by $35 \%$ since 1990 . 
The continued high producer support to agriculture and the system of border protection has adverse effects on productivity in the agricultural sector and beyond. Improving the efficiency and competitiveness of the sector should be high on the agenda for Swiss agricultural policymakers. Reducing the overall level of support would enhance competition, induce farms to produce more efficiently, freeing up scarce labour and capital for more productive endeavours, and lower input costs for the food processing industry. Also, the shift from market-price support to direct payments should be continued more vigorously as many product-specific price supports are still in place.

Currently only $20 \%$ of direct payments are dedicated to achieving environmental protection and animal welfare, the rest being "general" direct payments. Even though the new policy regime for 2014-17 will better target direct payments to improving spending efficiency and achieving policy objectives in a less costly fashion it is clear that the government could have gone faster in this direction. Continuing to spend well over a billion francs per year to help ensure food supply security seems excessive, especially in view of the fact that Switzerland already holds emergency food reserves of several months domestic use for a variety of foodstuffs and could easily seek to ensure safe sources of import supplies - such as by agreeing free trade in farm products with the EU - and an efficient domestic sector. As recommended in the last Economic Survey (OECD, 2012), the government's 2014-17 plan will raise support for those projects with the highest potential for environmentally friendly production processes, and a levy on emissions-producing inputs such as fertilisers (as implemented by some other EU countries such as Austria, Finland and Sweden) would be helpful as part of an overall policy mix designed to achieve multiple agri-environmental goals. Setting a price on the emission of greenhouse gases from agricultural production would also improve the overall efficiency of Swiss climate-change policy.

In addition, downstream industries such as the food-processing sector benefit from a system of tariff protection and export refunds for locally processed agricultural products. It would be advisable to do a rigorous assessment of the impact of this policy on the entire farm and processing sectors and indeed on the economy at large over the longer term.

Also of concern is the fact that the share of public agricultural $\mathrm{R} \& \mathrm{D}$ expenditure in total agricultural support is low in Switzerland (1.5\%), below the EU27 and the OECD averages (both 2.2\%) (Figure 9).

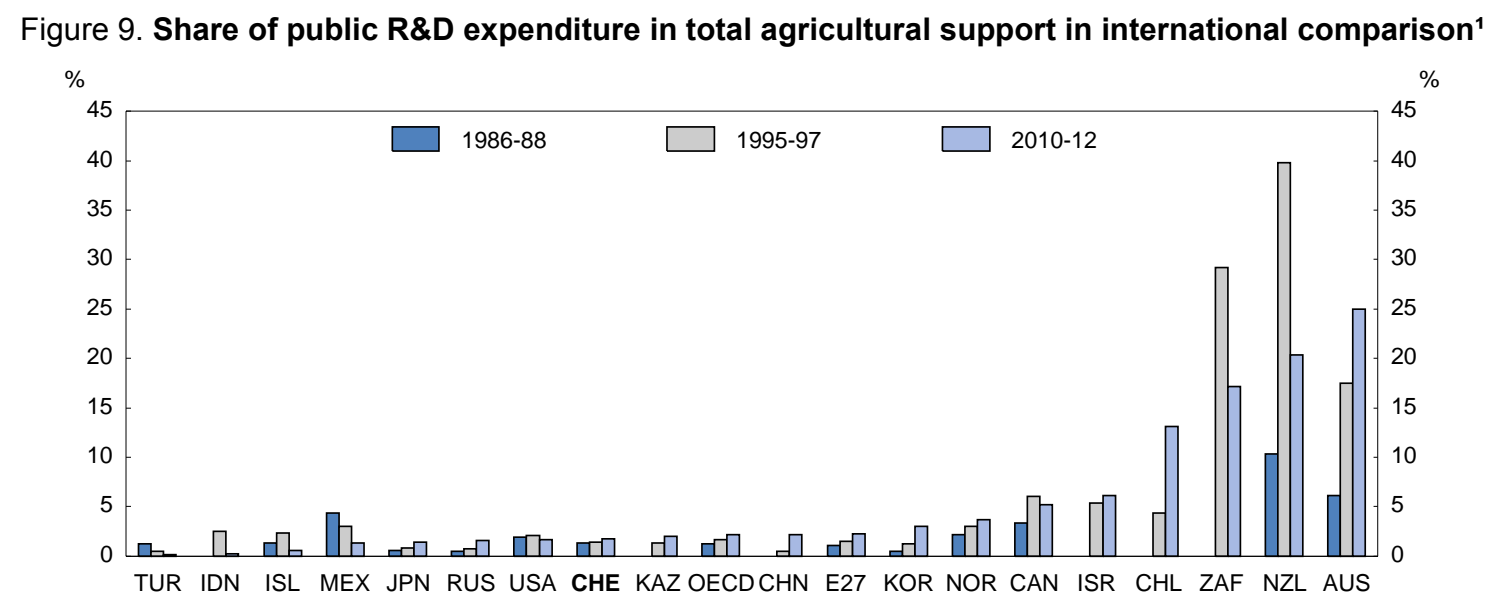

1. R\&D expenditures as a percentage of the Total Support Estimate (TSE).

Source: OECD.

Even if the Swiss shortfall would vanish if the figures were normalised on GDP, it would be prudent for the government not to disfavour this form of support. Technological progress can be a major source for improving productivity growth and allowing greater export orientation: most of the countries with 
export-focused farming sectors devote a large share of their public research budgets to agriculture. Empirical studies show that spending on $R \& D$ is an important component of agricultural innovation systems, with estimated rates of return of investments on agricultural R\&D ranging between 20 and $80 \%$ (OECD, 2011b). The next policy programme covering 2014-17 is supposed to focus on innovation and entrepreneurship in the agricultural sector (FOAG, 2011).

Another problem is that some parts of the food sector are artificially exempt from competition. The most severe case is that of the market for salt, whose structure is clearly sub-optimal in today's context. Two cantonal salt monopolies (regale $d u s e l$ ) - one for Vaud and the other for the rest - were originally intended to ensure security of supply. The cantons set the price, and tax and customs duties apply. Imports of salt and products with high salt content require producers' approval. This medieval system needs to be eliminated.

Finally, with food safety and security concerns coming to the fore in Europe, it is gratifying that new food safety legislation that will align the Swiss system with the European Union's acquis communautaire is expected to come into force in 2015. Most importantly, while Switzerland is still applying the so-called "positive principle" - all foreign produced foodstuffs are prohibited unless they are approved by the competent federal authorities - the new law will shift to the "precautionary principle" whereby only items where scientific evidence as to their safety is unclear are temporarily prohibited until a better informed judgement can be made, which is more in line with the EU's Cassis de Dijon principle.

\section{Box 2. Recommendations for public policies covering Switzerland's food and agriculture sector}

- $\quad$ Further efforts are needed to reduce the overall level of agricultural support, which would induce farms to produce more efficiently and promote structural adjustment.

- Security of food supply should be sought through a more competitive agriculture sector, ensuring access to stable sources of imports and, if necessary, emergency reserves, rather than heavy public support.

- The shift from market-price support to direct payments should be accelerated, beyond the government's plans. Direct payments should be better linked to policy objectives to improve spending efficiency and to achieve policy objectives at lower cost. A differentiated direct payment system can more effectively target support to yield benefits regarding the environment, biodiversity and landscape management, while potentially competitive producers, mainly in the lowlands, should be allowed more freedom to optimise their business. This will require a differentiated policy approach and a more vigorous move away from market price support and border protection and should be combined with the introduction of a levy on emissions-producing inputs, such as fertilisers.

- The system of border protection - involving, in particular, high import tariffs, an overly complex system of tariff rate quotas and export refunds for locally processed food products - should be substantially liberalised. As well, the impact of the measures impacting the downstream processing sector should be carefully assessed. The market for salt is an especially egregious case where competition has been prevented from functioning.

- Impediments to making agricultural land more mobile within the sector to achieve greater scale economies and shifting it to other uses (inheritance law and land price controls) should be completely removed.

- The focus on innovation in the agricultural sector should be increased, as officially envisaged. 


\section{Bibliography}

BFS (2011), Schweizer Landwirtschaft, Taschenstatistik 2011, Neuchâtel.

Chavaz, J. (2013), “Agricultural Policy in Switzerland: Where we come from, where we are heading", FOAG, Bern, 15 May.

DFE (Département fédéral de l'économie) (no date), "Rapport sur le tarif douanier", Bern.

FOAG (2011), “Weiterentwicklung der Agrarpolitik in den Jahren 2014 bis 2017”, Erläuternder Bericht zur Vernehmlassung zur Agrarpolitik 2014-2017, FOAG, Bern.

FOAG (2012a), Agricultural Report 2012, Federal Office for Agriculture, FOAG, Bern.

FOAG (2012b), "Conséquences de différents scénarios portant sur l'allocation des moyens financiers dans le cadre de la politique agricole 2014-2017”, FOAG, Bern, 23 May

FOAG (2013), "Direct payments: old/new system", presentation to an OECD delegation, Bern, 15 May.

Hofer, E. (2009), A Survey of Swiss Agricultural Policy Reform (1982-2007), FOAG, Bern.

Jörin, R. and Y. Lengwiler (2004), "Learning from Financial Markets: Auctioning Tariff-Rate Quotas in Agricultural Trade", Swiss Journal of Economics and Statistics, December.

Lanz, S. (2012), “Article on economics: Main aspects of the Agricultural Policy for 2014-2017”, FOAG, Bern.

Lehman, B. and S. Lanz (2012), "Les grandes lignes de la politique agricole 2014-2017”, La Vie économique, Revue de politique économique, 4-2012, pp. 4-8.

OECD (2007), Economic Survey of Switzerland, OECD Publishing.

OECD (2011a), Agricultural Policies in the OECD Countries and in Emerging Economies, OECD Publishing.

OECD (2011b), Fostering Productivity and Competitiveness in Agriculture, OECD Publishing.

OECD (2012), Economic Survey of Switzerland, OECD Publishing.

OECD (2013), Agricultural Policy Monitoring and Evaluation 2013, OECD Publishing.

OFS (2013), Agriculture Suisse, Statistique de poche 2013, Neuchâtel.

World Trade Organization (WTO) (2013), Trade Policy Review, Review by the Secretariat: Switzerland and Liechtenstein, WT/TPR/S/280, 19 March.

Zimmermann, A., A. Möhring, S. Mann and M.-P. Gennaio (2011), "Les conséquences d'une réforme du système des paiements directs; Simulations à l'aide de modèles SILAS et SWISSland", Rapport ART 744, DFE, Agroscope Reckenholz-Tänikon, March.

Zimmermann, A. et al. (2012), “Auswirkungen der Agrarpolitik 2014-2017, Aktualisierung des wichtigsten Ergebnisse des ART-Berichts Nr. 744”, Tänikon, cited in Lanz (2012) above. 
ECO/WKP(2013)78

\section{WORKING PAPERS}

The full series of Economics Department Working Papers can be consulted at www.oecd.org/eco/workingpapers/

1085. Japan's challenging debt dynamics

(August 2013) by Yvan Guillemette and Jan Strasky

1084. Transitions in and out of unemployment among young people in the Irish recession

(August 2013) by Elish Kelly, Seamus McGuinness, Philip O'Connell, David Haugh and Alberto González Pandiella

1083. Is there convergence of Russia's regions? Exploring the empirical evidence: 1995-2010

(August 2013) by Hartmut Lehmann and Maria Giulia Silvagni

1082. The benefits and costs of highly expansionary monetary policy

(August 2013) by Łukasz Rawdanowicz, Romain Bouis and Shingo Watanabe

1081. The effectiveness of monetary policy since the onset of the financial crisis

(August 2013) by Romain Bouis, Łukasz Rawdanowicz, Jean-Paul Renne, Shingo Watanabe and Ane Kathrine Christensen

1080. Responding to key well-being challenges in Austria

(August 2013) by Rauf Gönenç, Oliver Röhn, Christian Beer and Andreas Wörgötter

1079. Austria's well-being goes beyond GDP

(August 2013) by Oliver Röhn, Rauf Gönenç, Christian Beer and Romina Boarini

1078. Improving fiscal federal relations for a stronger Mexico

(August 2013) by Aida Caldera Sánchez

1077. Deleveraging: challenges, progress and policies

(August 2013) by Romain Bouis, Ane Kathrine Christensen and Boris Cournède

1076. Policies to support sustainable long-term growth in New Zealand

(July 2013) by Calista Cheung

1075. Do structural policies affect macroeconomic stability?

(July 2013) by Volker Ziemann

1074. A simple fiscal stress testing model - case studies of Austrian, Czech and German economies (July 2013) by Ondra Kamenik, Zdenek Tuma, David Vavra and Zuzana Smidova

1073. Road connectivity and the border effect: evidence from Europe

(July 2013) by Henrik Braconier and Mauro Pisu

1072. Fiscal consolidation across government levels. Part 3: Intergovernmental grants, pro- or counter-cyclical?

(July 2013) by Hansjörg Blöchliger and Balázs Égert 
1071. Fiscal consolidation across government levels. Part 2: Fiscal rules for sub-central governments, update of the institutional indicator

(July 2013) by Kaja Fredriksen

1070. Fiscal consolidation across government levels. Part 1: How much, what policies?

(July 2013) by Hansjörg Blöchliger

1069. Restructuring the electricity sector and promoting green growth in Japan

(June 2013) by Randall S. Jones and Myungkyoo Kim

1068. Labour market policies to promote growth and social cohesion in Korea

(June 2013) by Randall S. Jones and Satoshi Urasawa

1067. Education reform in Korea

(June 2013) by Randall S. Jones

1066. Belgium: enhancing the cost efficiency and flexibility of the health sector to adjust to population ageing

(June 2013) by Stéphane Sorbe

1065. Italy and the euro area crisis: securing fiscal sustainability and financial stability (June 2013) by Oliver Denk

1064. Policy implementation in Italy: legislation, public administration and the rule of law (June 2013) by Paul O’Brien

1063. Greening growth in Luxembourg

(June 2013) by Nicola Brandt

Vers une croissance plus verte en Luxembourg

(juin 2013) par Nicola Brandt

1062. The post-crisis narrowing of international imbalances - cyclical or durable?

(June 2013) by Patrice Ollivaud and Cyrille Schwellnus

1061. Restructuring welfare spending in Slovenia

(June 2013) by Rafał Kierzenkowski

1060. The economics of civil justice: new cross-country data and empirics

(August 2013) by G. Palumbo; G. Giupponi; L. Nunziata and J. Mora-Sanguinetti

1059. Banks' restructuring and smooth deleveraging of the private sector in Slovenia

(June 2013) by Olena Havrylchyk

1058. Assessing the efficiency of welfare spending in Slovenia with data envelopment analysis (June 2013) by Matevz Hribernik and Rafał Kierzenkowski

1057. Policy determinants of school outcomes under model uncertainty: evidence from South Africa (June 2013) by Thomas Laurent, Fabrice Murtin, Geoff Barnard, Dean Janse van Rensburg, Vijay Reddy, George Frempong and Lolita Winnaar 